\title{
A rare complication of ulcerative colitis in children: Pyoderma gangrenosum
}

\section{Çocuklarda ülseratif kolitin nadir bir komplikasyonu: Piyoderma gangrenozum}

\author{
Ulas Emre Akbulut ${ }^{1}$, Ishak Abdurrahman Isik ${ }^{1}$, Bilge Aldemir $\operatorname{Kocabas}^{2} \mathbb{E}$, Fatih Ay $^{3} \mathbb{E}$, Hulya Tosun Yildirim ${ }^{4}$ \\ ${ }^{1}$ Dept. of Pediatric Gastroenterology Hepatology and Nutrition, University of Health Sciences, Antalya Training and Research Hospital, Antalya, \\ Turkey, ${ }^{2}$ Dept. of Pediatric Infectious Diseases, University of Health Sciences, Antalya Training and Research Hospital, Antalya, Turkey, ${ }^{3}$ Dept. \\ of Pediatrics, University of Health Sciences, Antalya Training and Research Hospital, Antalya, Turkey, ${ }^{4}$ Dept. of Pathology, University of Health \\ Sciences, Antalya Training and Research Hospital, Antalya, Turkey
}

\section{Abstract}

Pyoderma gangrenosum (PG) is a rare inflammatory skin disease mainly characterized by ulcers. More than half of the PG is associated with systemic diseases like inflammatory bowel disease. About $4 \%$ of PG is seen during childhood. Here we report a 12-year-old girl presented with fever and bloody diarrhea and who developed a painful leg ulcer during follow up period and diagnosed as ulcerative colitis.

Key words: ulcerative colitis, pyoderma gangrenosum, children

\section{O̊zet}

Piyoderma gangrenozum (PG), esas olarak ülserlerle karakterize nadir görülen bir inflamatuar deri hastalığıdır. PG'nin yarısından fazlası, inflamatuar bağırsak hastalığı gibi sistemik hastalıklarla ilişkilidir. Olguların yaklaşık \%4'ü çocukluk döneminde görülür. Burada ateş ve kanlı ishal ile başvuran, takip döneminde ağrılı bacak ülseri gelişen ve ülseratif kolit tanısı konulan 12 yaşında bir kız hastayı sunuyoruz.

Anahtar kelimeler: ülseratif kolit, piyoderma gangrenozum, çocuklar

\section{Introduction}

Pyoderma gangrenosum (PG), first defined at 1930, is a rare non-infectious dermatologic disease characterised by single or multiple ulcers. Characteristic skin lesions with unremarkable border can be seen all over the body but mostly at lower extremities. ${ }^{1}$ More than half of the PG is associated with systemic diseases like inflammatory bowel disease, haematological diseases or arthritis. ${ }^{2}$ About 4\% of PG is seen during childhood. ${ }^{3}$ Here we report clinical features, diagnostic progress and treatment results of a 12-year-old girl presented with fever and bloody diarrhea and who developed a painful leg ulcer during follow up period and diagnosed as ulcerative colitis.

Corresponding author: Ulas Emre Akbulut, Dept. of Pediatric Gastroenterology Hepatology and Nutrition, University of Health Sciences, Antalya Training and Research Hospital, Antalya, Turkey, Phone: +90 24224944 00, E-mail: ulasemre@hotmail.com

Received: 6 March 2020 Accepted: 27 March 2020

Conflict of Interest: None.

Funding: None

(c) (i) (8) This work is licensed under a Creative Commons Attribution-NonCommercial 4.0 International License. 


\section{Case report}

A 12-year-old girl was admitted to our clinic with fever and bloody diarrhea. She had a history of bloody diarrhea 10-12 times in a day for three weeks and intermittent fever of $39^{\circ} \mathrm{C}$. Her family histories were not relevant. On physical examination her body weight was $50 \mathrm{~kg}$ (50 to 75 percentile), and height was 157 $\mathrm{cm}$ (75 percentile). She seemed pallor and her body temperature, pulse rate, arterial tension and breath rate were $38^{\circ} \mathrm{C}, 92 / \mathrm{min}, 100 / 70 \mathrm{mmHg}$ and $22 / \mathrm{min}$, respectively. Her physical examination was notable for tenderness all over the abdomen and hyperactive intestinal sounds. She also had a few aphthous lesions in her mouth (previously, she had no history of oral aphthous lesions). On her laboratory examination, haemoglobin level was $7.1 \mathrm{gr} / \mathrm{dL}$, white blood cell counts

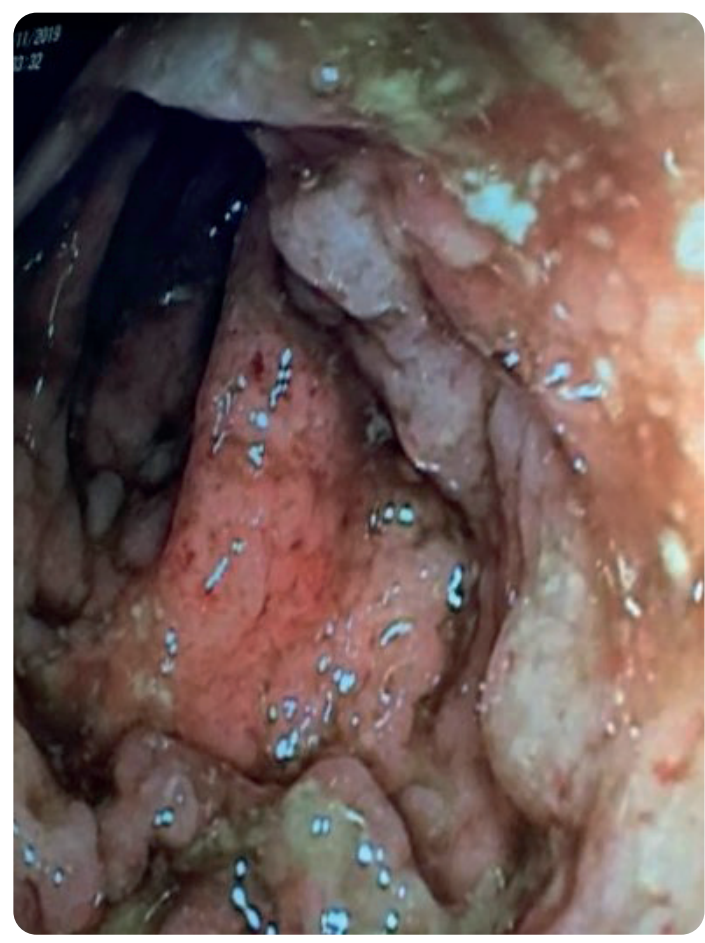

Fig. 1. Endoscopic appearance of ulcerative colitis

were $21700 \mathrm{cell} / \mathrm{mm}^{3}$, platelets were $753000 \mathrm{cell} / \mathrm{mm}^{3}$, erythrocyte sedimentation rate was $36 \mathrm{~mm} / \mathrm{h}$, C-reactive protein was $107 \mathrm{mg} / \mathrm{dL}$, albumin level of plasma was $2.4 \mathrm{gr} / \mathrm{dL}$, and total protein level was $5.2 \mathrm{~g} / \mathrm{dL}$. Her kidney function tests, reticulocyte count, direct coombs, prothrombin time, international normalisa- tion ratio, transaminases and bilirubin levels were in normal ranges.

The autoantibody screening tests (ANA, dsDNA) revealed no immunologic abnormalities. Stool tests were negative for Clostridium difficile, Salmonella, Yersinia, Campylobacter, Shigella and parasites. Serological tests for antibodies against HIV, Hepatitis A, B, C, Herpes simplex virus, Cytomegalovirus, Epstein-Barr virus and VDRL were also negative. PPD and quantiferon test were negative.

She had hyperaemia, granularity and fragility all over the colonic segments, but normal mucosa of terminal ileum in colonoscopy. There were irregular ulcers reaching $1 \mathrm{~cm}$ in diameter in some areas and full of exudate all over the mucosa of the colon. There were also widespread pseudopolips and pseudodiverticules (Fig. 1). Histopathological examination revealed active phase of ulcerative colitis.

At the third day of the hospitalisation, erythematous and tender subcutaneous nodules had developed on her lower extremities. Later these nodules were converted to deep ulcers circled with irregular purple-reddish halo (Fig. 2). Biopsy specimen from the border of the ulcer was in accordance with PG (Fig. 3).

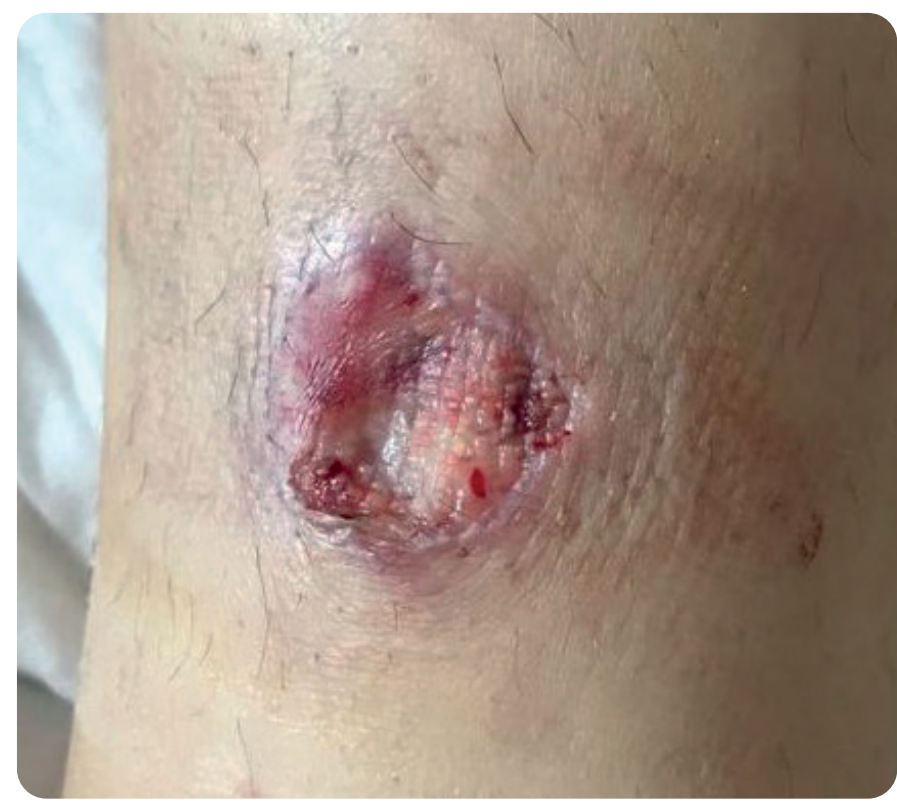

Fig. 2. The ulcer with an irregular purple-reddish halo on the leg of patient 
After the diagnosis of ulcerative colitis and PG, intravenous prednisolone ( $1 \mathrm{mg} / \mathrm{kg} /$ day) and mesalazine (30 $\mathrm{mg} / \mathrm{kg} /$ day) treatment was started. Topical corticosteroid was also applied for skin lesions. While tapering the systemic corticosteroid, azathioprine $(2 \mathrm{mg} / \mathrm{kg} /$ day) was added to the treatment.

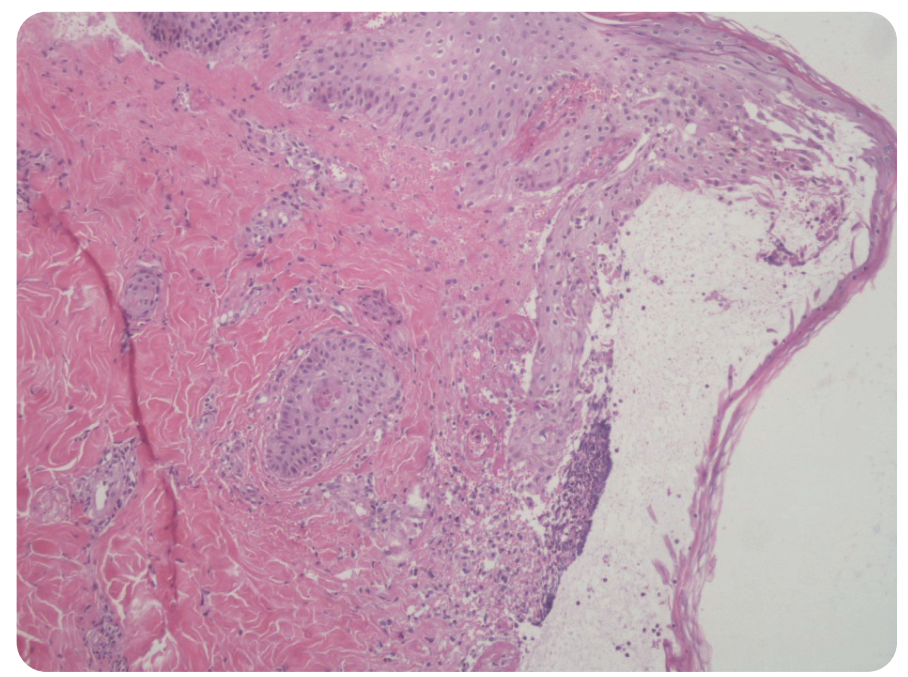

Fig. 3. Superficial ulceration with a mixed chronic inflammatory cells including mostly neutrophils (Hematoxylin \& eosin X 20)

After the second day of the treatment significant clinical recovery was observed. Healing of the skin ulcers and decrease in the number of the diarrhea were also observed. However, two ulcers were resistant to treatment.

Two weeks after systemic steroid treatment, intralesional steroid injection was applied to these ulcers. Complete recovery was observed in the ulcers after two intralesional injections, which was performed twice a month.

\section{Discussion}

PG is one of the non-infectious neutrophilic dermatosis which is frequently seen in lower extremities. It usually starts as papule, nodule or vesicular or pustular lesions rapidly converting to painful purulent ulcers with unremarkable borders. Although the pathogenesis of PG is still unclear, abnormal neutrophilic chemotacsis or hyperactivity or over expression of interleukin- 8 or 15 are thought to be associated with disease. ${ }^{4-6}$ Many of these effects may be mediated by the proinflammatory cytokine TNF- $\alpha$. For this reason, PG is often thought to be associated with autoimmune diseases. Cross reacting antigens might cause skin lesions in inflammatory bowel disease with which PG is mostly associated. ${ }^{5}$

PG has been reported in the pediatric population in association with inflammatory bowel disease, hematologic disorders (monoclonal gammopathy, myelofibrosis, myelogenous leukemia, and hairy cell leukemia), rheumatoid arthritis, Takayasu disease, and some infectious diseases (HIV and chronic hepatitis). ${ }^{2}$ In addition, PG has been associated with novel drug therapies like pegfilgrastim (granulocyte-stimulating factor) and gefitinib (inhibitor of epidermal growth factor receptor). ${ }^{3}$ Inflammatory bowel disease (especially ulcerative colitis) is the most common systemic disease associated with PG. PG usually occurs after months or years of initiation of the ulcerative colitis, regardless of the clinical course of the disease. Uncommonly skin lesions can be seen before the intestinal symptoms. In our case, PG occurred approximately one month after the intestinal symptoms of the patient started. Our patient presented with disease located on the legs, suggesting that gravitational dependency may predispose to PG. In addition this is an area often associated with trauma, which may play a significant role in PG development. ${ }^{7}$

Identifying and treating the underlying disorders are obligatory. The aim is to obtain stable, long-term control of the primary disease. Systemically applied corticosteroids are still first line drugs although there is no treatment algorithm yet. ${ }^{6,8}$ Topical treatment with moist wound management beside with systemic treatment is also beneficial. ${ }^{9}$ Severity of the skin lesions, general health status of the patient and underlying disease should be taken into consideration before deciding the treatment modality. In our case, all of the skin lesions except two ulcers were recovered with systemic steroid beside topical steroid. These two lesions were recovered completely with intralesional steroid injections. PG refractory to steroid treatment can be managed with immunomodulatory drugs or biological response modifiers. Successful results have been 
reported with mycophenolate mofetil, dapson, tacrolimus, thalidomide, cyclosporine, infliximab, adalimumab, and recombinant human epidermal growth factor. ${ }^{10-14}$ In addition, there are case reports demonstrating success with etanercept, ustekinumab, anakinra and canakinumab. ${ }^{15-18}$

In summary, PG is an inflammatory neutrophilic dermatosis associated with many systemic diseases including ulcerative colitis. Systemic corticosteroids are still the first-choice therapy in PG. Adding intralesional steroid injections to systemic corticosteroid therapy may increase the efficacy of the treatment, and heal the ulcers as in our patient with ulcerative colitis.

\section{References}

1. Arguelles-Arias F, Castro-Laria L, Lobaton T, et al. Characteristics and treatment of pyoderma gangrenosum in inflammatory bowel disease. Dig Dis Sci 2013;58:2949-54.

2. Soleimani T, Sasor SE, Spera L, et al. Pediatric pyoderma gangrenosum: is it just big wounds on little adults? J Surg Res 2016;206:113-7.

3. Kechichian E, Haber R, Mourad N, et al. Pediatric pyoderma gangrenosum: a systematic review and update. Int J Dermatol 2017;56:486-95.

4. Bissonnette C, Kauzman A, Mainville GN. Oral pyoderma gangrenosum: diagnosis, treatment and challenges: a systematic review. Head Neck Pathol 2017;11:427-41.

5. Niu R, Zheng J, Ding D, et al. Giant pyoderma gangrenosum in a patient with ulcerative colitis: A case report. Medicine (Baltimore) 2020;99:e18795.

6. Zampeli VA, Lippert U, Nikolakis G, et al. Disseminated refractory pyoderma gangraenosum during an ulcerative colitis flare.Treatment with infliximab. J Dermatol Case Rep 2015;9:62-6.

7. Brooklyn T, Dunnill MG, Probert C. Diagnosis and treatment of pyoderma gangrenosum. BMJ 2006;22:181-4.

8. Miller J, Yentzer BA, Clark A, et al. Pyoderma gangrenosum: a review and update on new therapies. J Am Acad Dermatol 2010;62:646-54.

9. Wollina U. Pyoderma gangrenosum: a review. Orphanet J Rare Dis 2007;15:1-8.

10. Futami H, Kodaira M, Furuta $T$, et al. Pyoderma gangrenosum complicating ulcerative colitis: Successful treatment with methylprednisolone pulse therapy and cyclosporine. J Gastroenterol 1998;33:408-11.
11. Powell RJ, Holbrook MR, Stevens A. Pyoderma gangrenosum and its treatment. Lancet 1997;350:1720-1.

12. Gettler S, Rothe M, Grin C, et al. Optimal treatment of pyoderma gangrenosum. Am J Clin Dermatol 2003;4:597-608.

13. Regueiro M, Valentine J, Plevy S, et al. Infliximab for treatment of pyoderma gangrenosum associated with inflammatory bowel disease. Am J Gastroenterol 2003;98:1821-6.

14. Kim TY, Han DS, Eun CS, et al. Recombinant human epidermal growth factor enhances wound healing of pyoderma gangrenosum in a patient with ulcerative colitis. Inflamm Bowel Dis 2008;14:725-7.

15. Charles CA, Leon A, Banta MR, et al. Etanercept for the treatment of refractory pyoderma gangrenosum: a brief series. Int J Dermatol 2007;46:1095-9.

16. Fahmy M, Ramamoorthy S, Hata T, et al. Ustekinumab for peristomal pyoderma gangrenosum. Am J Gastroenterol 2012;107:794-5.

17. Brenner M, Ruzicka T, Plewig G, et al. Targeted treatment of pyoderma gangrenosum in PAPA (pyogenic arthritis, pyoderma gangrenosum and acne) syndrome with the recombinant human interleukin-1 receptor antagonist anakinra. Br J Dermatol 2009;161:1199-201.

18. Geusau A, Mothes-Luksch N, Nahavandi H et al. Identification of a homozygous PSTPIP1 mutation in a patient with a PAPA-like syndrome responding to canakinumab treatment. JAMA Dermatol 2013;149:209-15. 